\title{
Block Island Wind Farm
}

\section{Methods}

\section{Research Fellow:}

Aidan Ackerman

Assistant Professor

SUNY College of Environmental Science and Forestry

Robin Hoffman

Associate Professor

SUNY College of Environmental Science and Forestry

Maren King

Associate Professor

SUNY College of Environmental Science and Forestry

\section{Research Assistant:}

Meaghan Keefe

MLA Candidate

SUNY College of Environmental Science and Forestry

\section{Firm Liaison:}

Gordon Perkins

Senior Project Manager

Environmental Design and Research

This investigation was conducted as part of the Landscape Architecture Foundation's 2019 Case Study Investigation (CSI) program. CSI matches faculty-student research teams with design practitioners to document the benefits of exemplary high-performing landscape projects. Teams develop methods to quantify environmental, social, and economic benefits and produce Case Study Briefs for LAF's Landscape Performance Series.

To cite: Ackerman, Aidan, Robin Hoffman, Maren King, and Meaghan Keefe. "Block Island Wind Farm Methods." Landscape Performance Series. Landscape Architecture Foundation, 2019. https://doi.org/10.31353/cs1531

The full case study can be found at: https://landscapeperformance.org/case-study-briefs/blockisland-wind 


\section{Environmental Benefits}

- Generates an estimated 18,396,000 kWh of wind power per year, providing essentially $100 \%$ of energy needs for all households on Block Island and an estimated 12,500 households on the Rhode Island mainland. This eliminates the need for up to 456,900 gallons of diesel fuel per year for generators on Block Island, as well as the cost of transporting fuel to the island.

Methods: Industry estimates were used, as actual data on output was not available. Industry estimates project an annual output of $30-40 \%$ of a wind turbine's maximum capacity. With a $35 \%$ capacity factor, a 6-MW turbine would produce $18,396,000 \mathrm{kWh}$ per year. In 2017 , the average annual electricity consumption for a Rhode Island residential utility customer was 7,112 kilowatt hours (kWh), an average of $593 \mathrm{kWh}$ per month. At this average annual electricity consumption, the 5-turbine wind farm could power 12,935 households annually, which significantly exceeds the approximately 443 households on Block Island.

Total \# Block Island households (2017): 443

Calculations:

To calculate the percentage of household energy use supplied by BIWF:

$6 \mathrm{MW} \times 365$ days $\times 24$ hours $\times 35 \%=18,396 \mathrm{MWh}=18,396,000 \mathrm{kWh}$ per year

$18,396,000 \mathrm{kWh}$ turbine output per year / 7,112 kWh average Rhode Island State residential household energy consumption per year $=2,587$ homes powered per year

2,587 homes per year $\times 5$ wind turbines $=12,935$ households powered per year

12,935 households -443 households (Block Island) $=$ approximately 12,492 households on the Rhode Island mainland

To calculate the amount of diesel generator fuel saved:

$1 \mathrm{kWh}=3412.14163312794 \mathrm{BTU}_{\mathrm{IT}}$

Therefore, the energy in BTUs $E_{(B T U)}$ is equal to $3412.1416 x$ the energy in kilowatt-hour $\mathrm{E}_{(\mathrm{kWh})}: \mathrm{E}_{(\mathrm{BTU})}=3412.14163312794 \times \mathrm{E}_{(\mathrm{kWh})}$

$18,396,000 \mathrm{kWh}=62,769,757,639$ BTUs

1 gallon of diesel fuel $=137,381 \mathrm{Btu}$ (for distillate fuel with $15 \mathrm{ppm}$ or less sulfur content) 
$62,769,757,639 / 137,381$ BTUs $=456,902$ gallons of diesel fuel saved

Sources:

U.S. Energy Information 2017, Average Monthly Bill- Residential (Data from forms EIA-861schedules 4A-D, EIA-861S and EIA-861U). U.S. Energy Information Administration.

Point2Homes. "Block Island Demographics", www.Point2Homes.com. https://www.point2homes.com/US/Neighborhood/RI/New-Shoreham/Block-IslandDemographics.html (Accessed June 1, 2019)

U.S. Energy Information Administration, "Energy Units and Calculators Explained, Energy Conversion Calculators" https://www.eia.gov/energyexplained/index.php?page=about energy conversion calculator (accessed June 1, 2019)

Limitations: We were unable to access the actual turbine output for the wind farm, instead needing to use estimates for 6-MW turbines. Additionally, although the wind farm's output far exceeds the needs of Block Island residents, there is no specific information available about where on the mainland the additional energy is directed. Therefore, to align with the estimate of Block Island households, we decided to estimate and express the additional energy output in terms of households on the mainland.

- Provides aquatic habitat for marine life including cod, black sea bass, and mussels. $44 \%$ of 25 interviewed fishers reported additional fish species in the area surrounding the turbine bases, and $36 \%$ reported establishment of mussels on turbine bases.

Methods: In person, semi-structured interviews were conducted with 25 fishers based mainly out of New Shoreham on Block Island and Narragansett on mainland Rhode Island. Participants were both commercial and recreational fishers. Fishers were asked about their perceptions of changes in the marine ecology of the wind farm area during and after the offshore wind turbines were constructed, and how their activities in the area have changed since the wind farm was installed.

\section{Calculations:}

20 out of 25 fishers ( $80 \%$ ) interviewed noted that the underwater turbine bases created new structure for fish habitat, specifically through mussel growth and larger numbers of fish in those areas

11 out of 25 fishers (44\%) noted additional fish species in the area surrounding turbine bases in interviews 
9 out of 25 fishers (36\%) noted establishment of mussels on turbine bases in interviews

5 out of 25 fishers (20\%) noted more cod in areas surrounding turbine bases

\begin{tabular}{|l|l|l|l|}
\hline Identified Themes & $\begin{array}{l}\text { No. of } \\
\text { Respondents } \\
\text { (out of 25 total } \\
\text { fishers) }\end{array}$ & $\begin{array}{l}\text { No. } \\
\text { Commercial } \\
\text { (out of 7) }\end{array}$ & $\begin{array}{l}\text { No. } \\
\text { Recreational } \\
\text { (out of 18) }\end{array}$ \\
\hline $\begin{array}{l}\text { "Structure" or "reef" or "fish aggregating" as } \\
\text { rationale for fish behavior }\end{array}$ & 20 & 3 & 17 \\
\hline Additional fish species noted in the area & 11 & 0 & 11 \\
\hline Establishment of 'mussels' and other habitat & 9 & 1 & 8 \\
\hline $\begin{array}{l}\text { More cod in the area (personal and indirect } \\
\text { experience }\end{array}$ & 5 & 0 & 5 \\
\hline
\end{tabular}

Table 1. Perceived offshore wind farm impacts described during interviews with fishers: regarding impacts on ecological systems

Source: ten Brink and Dalton, 2018

Greater abundance of fish near subsurface wind turbine structures may be considered as supported by a meta analysis of studies of fin-fish abundance at offshore wind farms in which 96 records of abundance in 13 research papers showed an overall positive and statistically significant abundance of fin fish near subsurface wind turbine structures when compared to reference sites.

Sources:

Talya S. ten Brink, and Tracey Dalton. 2018. "Perceptions of Commercial and Recreational Fishers on the Potential Ecological Impacts of the Block Island Wind Farm (US)". Frontiers in Marine Science.

Methratta, Elizabeth T., and William R. Dardick. 2019. "Meta-Analysis of Finfish Abundance at Offshore Wind Farms". Reviews in Fisheries Science \& Aquaculture. 27 (2): 242-260.

\section{Limitations:}

Results were not independently verified by the research team. Limitations of this study include the relatively small sample size, and that these are reports of personal and in some cases indirect experiences. This limits the generalizability of the study. Impacts of turbine construction on the marine environment were not considered in this analysis. 


\section{Social Benefits}

- Yielded neutral to positive perception of the project's aesthetic and social value among tourists, locals, and business owners from year 2 to year 3 after project completion. Wind farm-related tourism increased and negative perceptions of the wind farm decreased.

\section{Methods:}

To understand change in opinion, we referenced a two-year participant observation study that found that general attitudes towards the BIWF were neutral to positive across tourists, locals, and business owners. On Block Island itself, the authors of the study found changes in tourism in the form of new merchandise (bumper stickers, postcards, etc.) that featured the BIWF as an attraction. They also recorded the existence of tours to view the BIWF (by taxi, ferry, and helicopter), and general interest such as seeking to take photos with the BIWF in the background. Additionally, the researchers concluded that the turbines were viewed as less controversial in the second year after the completion of the turbines than in the first year.

The study also included a focus group whose participants shared that their experiences surrounding the wind farm were largely positive, and a majority of participants agreed that the wind farm acted as an attractant and that the aesthetics fit into the coastal environment. The focus groups consisted of six 105-minute sessions, and included 40 participants from 5 different sectors (including both boat based and land based tourism activities). Over the course of this two year study, 24 sites distributed on Block Island, the Rhode Island mainland, and regional waters were chosen for extensive participant observation based on available views of the Block Island Wind Farm (BIWF). During participant observation, each site was assessed and documented using handwritten notes and photographs. Recorded notes included information on site exploration (space, mobility/access, sociospatial dynamics, environmental conditions, key features), social scene (who, how many, what, when, social dynamics, coherence/difference, inclusion/exclusion, types of behaviors/practices), conversation, participation in activities (embodied sensations , aspects of enjoyment, key to the experience), and contextualization (situate observations within relevant current and historical events and social, cultural, and political situations). Notes were taken in the form of handwritten scratch notes (quick observational notes when longer periods of writing were not appropriate) and handwritten field notes (more detailed observational notes), and were ultimately typed and composed into field summaries. Additionally, informal open-ended and unstructured interviews were conducted with a number of individuals representing business owners, local residents, employees, and tourists/visitors. Notes, interviews, and observations focused on activities, comments, and conversations relevant to the BIWF. 


\begin{tabular}{|l|l|l|l|}
\hline & Block Island & Mainland Rhode Island & Regional Waters \\
\hline Year 1 (2017) & Visitor Center & Scarborough Beach & Block Island Commuter Ferry \\
& Water Street & Fisherman's Memorial & Block Island Express Ferry \\
& Businesses & Beach & Frances Fleet Whale Watching \\
& Southeast Light & East Matunuck Beach & Block Island Ferry Wind Farm \\
& Mohegan Bluffs & Roy Carpenter's Beach & Tour \\
& Second Bluff & Salty Brine State Beach & Recreational Fishing Boat \\
& Van Tours & Green Hill Beach & Charter Wind Farm Tour \\
& Real Estate Offices & Charlestown Town & \\
Ballard's Beach & Beach & \\
\hline Year 2 (2018) & Visitor Center & Scarborough Beach & Block Island Commuter Ferry \\
& Water Street & Fisherman's Memorial & Block Island Express Ferry \\
& Businesses & Beach & Charter Wind Farm Tour \\
& Southeast Light & East Matunuck Beach & \\
& Mohegan Bluffs & Roy Carpenter's Beach & \\
Second Bluff & Salty Brine State Beach & \\
& Fred Benson Town & Charlestown Town & \\
& Beach & Beach & \\
& Block Island Airport & & \\
\hline
\end{tabular}

Table 2: Sites of Participant Observation

Source: Smith et al. 2018

Source:

T. Smythe, H. Smith, A. Moore, D. Bidwell, J. McCann, 2018. Methodology for Analyzing the Effects of Block Island Wind Farm (BIWF) on Rhode Island Recreation and Tourism Activities. U.S. Department of the Interior, Bureau of Ocean Energy Management, Sterling, VA. OCS Study BOEM 2018-068. 84 pp.

\section{Limitations:}

Results were not independently verified by the research team. While the referenced study showed a generally positive response to the BIWF, the main aim of the study was to work to identify indicators that would aid in assessing the social reception of offshore wind farms in general, therefore emphasis was not placed on obtaining quantitative, targeted results.

From the study: "[Participant observation] (PO) emphasizes qualitative and interpretive methods over quantitative methods due to this being the first study focused on offshore wind farm coverage. There is a great deal that is unknown prior to study initiation which requires more open ended and exploratory work and which prevents more targeted research design. This means that statistical tests of significance cannot be performed on this data, nor is that an appropriate expectation for ethnographic information. PO is limited to the time available for researchers to conduct fieldwork and by the spaces, activities, and events they have access to as members of society in general. There are many events we could not attend due to lack of 
man-power, as well as many social settings it would not have been appropriate for us to attend (such as private functions in private spaces)."

- Reduced noise pollution for island residents by eliminating diesel generators as the primary power source. The average noise reduction was 14 decibels, the equivalent of cutting experienced sound levels by more than half.

\section{Methods:}

The Block Island Power Company is located midway up the eastern coast of Block Island, less than 0.1 miles inland. Prior to the construction of the Block Island Wind Farm, four Caterpillar 3516 (1200-1800 rpm) diesel generators were the sole source of electricity for the island. The generators' fuel supply was fulfilled by shipments of diesel carrier trucks via ferry to the island. The nearest residence to the generators is 0.05 miles away, and within a mile of the generators are several rental properties and inns as well as a public beach, multiple ponds with public or residential access, and public parks. The street on which the Block Island Power Company is located receives regular car, bicycle, and pedestrian traffic during the summer months, increasing the number of people who were exposed to sound pollution in the vicinity of the generators. Sites for sound measurements were selected to be representative of areas where people might a) be exposed the most to the sound of the generators, b) value other ambient sounds that were reduced or eliminated at the expense of the generator sound, or $\mathrm{c}$ ) value the serenity or quiet of natural or residential areas.

Sound measurements in decibels $(\mathrm{dB})$ were taken at five separate points on Block Island during a single day (7/9/19) in the month of July. The Sper Scientific Advanced Datalogging Sound Meter (Model 850013) was used for all field measurements, which uses a single range of 30 to $130 \mathrm{~dB}$. This sound meter has a $0.1 \mathrm{~dB}$ resolution and $\pm 1.0 \mathrm{~dB}$ accuracy, and meets or exceeds all other specs for an IEC 61672:2013 Class 2 and ANSI S1.4:2014 Type 2 meter. Measurements were first taken with the diesel generators turned off (as they typically are, except in rare circumstances). Measurements were then taken from the same locations with all four of the island's diesel generators in operation. These measurements were taken with the Model 850013 Sper Scientific Sound Meter over the course of 10 minutes of consistent monitoring. Site conditions, time of day, temperature, weather, and other contextual data were noted on a measurement report sheet for each site.

Due to decibels being measured on a logarithmic scale, some explanation of their significance is required. The threshold of perception of the human ear is approximately $3 \mathrm{~dB}$, a $5 \mathrm{~dB}$ change is considered to be clearly noticeable, and a $10 \mathrm{~dB}$ change would be perceived to be twice as loud (Minnesota Pollution Control Agency, 2015). To calculate the perceived noise reduction on Block Island, the difference in average sound levels from sites 1, 2, and 5 was entered into calculators at www.sengpielaudio.com which convert sound level in $\mathrm{dB}$ to a metric of relative loudness. This calculator determined that by the increase in average ambient sound attributable to the generators at these three sites would be perceived as 2.66 times louder than if they were turned off. 


\section{Sound level change and loudness ratio}

To use the calculator, simply enter a value.

The calculator works in both directions of the $\leftrightarrow$ sign.

\begin{tabular}{|l|l|l|}
\hline $\begin{array}{l}\text { Level change } \Delta L_{\text {loud }} \text { (psychoacoustics) } \\
14.13 \quad \mathrm{~dB}\end{array}$ & $\leftrightarrow$ & $\begin{array}{l}\text { Ratio } x \text { for loudness (volume) } \\
2.662903 \text { times }\end{array}$ \\
\hline$\Delta L=10 \cdot \log _{2} x=33.22 \cdot \log (x)$ & & $x=10^{\frac{\Delta L}{33,22}}=2^{\frac{\Delta L}{10}}$ \\
\hline
\end{tabular}

Figure 1. A screen capture from www.sengpielaudio.com shows the relative loudness of the change in decibels of 2.662903 times quieter from generators turned on to generators turned off.

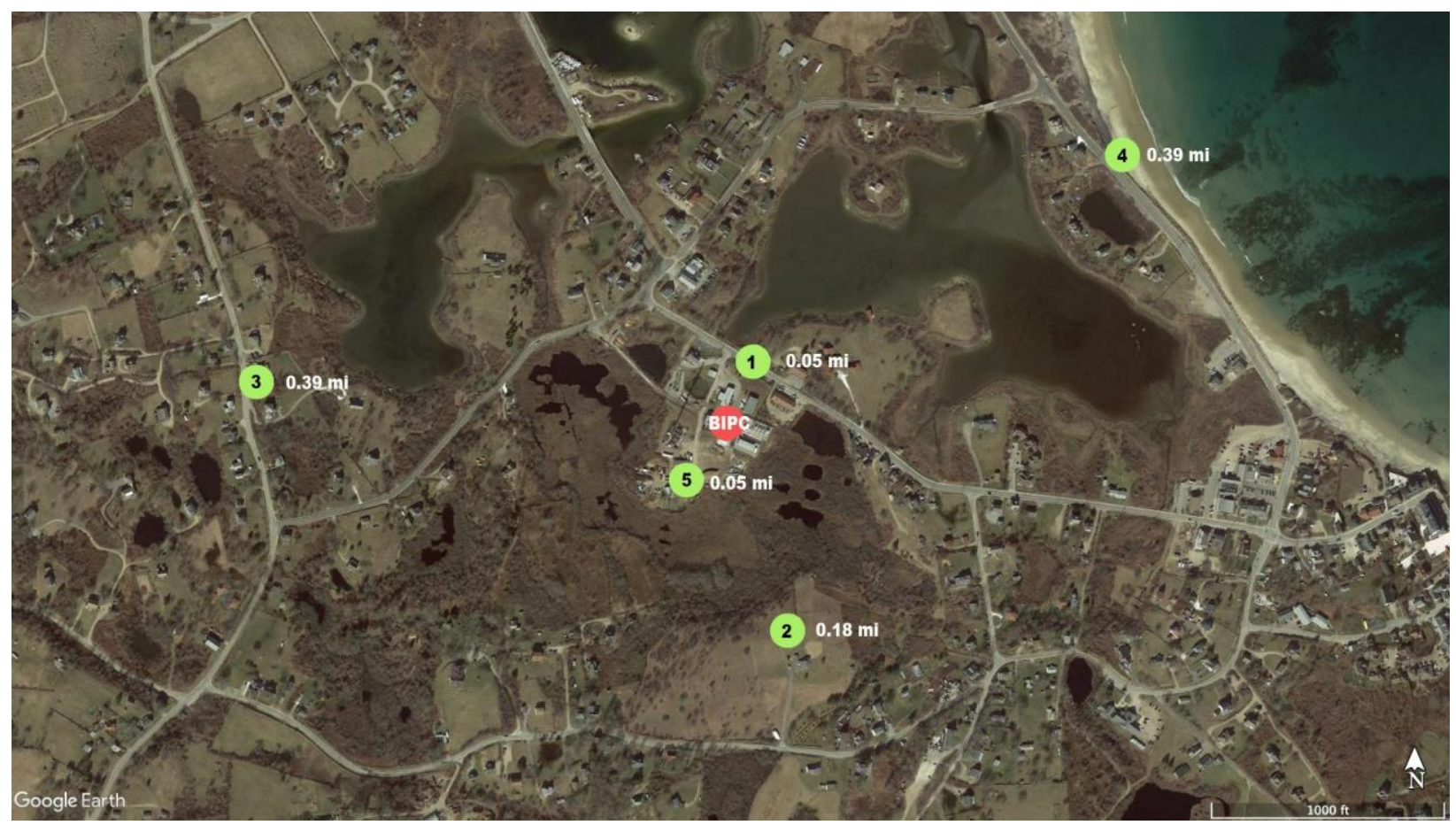

Figure 2. This map shows the 5 sites (green) where generator sound measurements were taken relative to the Block Island Power Company (red). Distance from the generators in miles is indicated next to each site marker. 


\begin{tabular}{|c|c|c|c|c|c|}
\hline & SITE 1 & SITE 2 & SITE 3 & SITE 4 & SITE 5 \\
\hline MONITORING DATE & $7 / 9 / 19$ & $7 / 9 / 19$ & $7 / 9 / 19$ & $7 / 9 / 19$ & $7 / 9 / 19$ \\
\hline \multicolumn{6}{|l|}{ NOISE READINGS } \\
\hline GENERATORS OFF (dB) RANGE & $41.5-66.6$ & $38.9-57.5$ & 41.1-53.9 & $42.2-61.5$ & $46.2-59.4$ \\
\hline START TIME & 8.05 & $8: 54$ & $8: 39$ & $8: 23$ & $9: 10$ \\
\hline STOP TIME & $8: 15$ & 9:04 & $8: 49$ & $8: 33$ & $9: 20$ \\
\hline GENERATORS ON (dB) RANGE & $66.9-73.3$ & $49.1-57.0$ & $39.1-67.3$ & $46.9-63.6$ & $65.4-79.1$ \\
\hline START TIME & $10: 21$ & $10: 06$ & $9: 51$ & 9:35 & $10: 33$ \\
\hline STOP TIME & $10: 31$ & $10: 16$ & $10: 01$ & $9: 45$ & $10: 43$ \\
\hline \multicolumn{6}{|l|}{ LOCATION } \\
\hline LOCATION ADDRESS & $41.1758,-71.57$ & $\begin{array}{r}492 \text { Old Town Rd, } 41.1726,- \\
71.5698\end{array}$ & $41.1765,-71.5779$ & $41.1782,-71.5639$ & $\begin{array}{r}8 \text { Ocean Ave, 41.1744, - } \\
71.5709\end{array}$ \\
\hline LOCATION DESCRIPTION & $\begin{array}{r}\text { Outside the BIPC front } \\
\text { gate }\end{array}$ & $\begin{array}{l}\text { On hill, yard of private } \\
\text { residence, close to BIPC }\end{array}$ & Yard overlooking pond & $\begin{array}{r}\text { beach, near large rock at } \\
\text { base of stairs }\end{array}$ & $\begin{array}{r}\text { closest residence behind } \\
\text { BIPC }\end{array}$ \\
\hline \multicolumn{6}{|l|}{ CONDITIONS } \\
\hline WIND & $\begin{array}{r}\text { NW 9mph, light breeze } \\
\text { but sheltered }\end{array}$ & NW 9mph, light breeze & $\begin{array}{r}\text { NW } 9 \text { mph, site mostly } \\
\text { sheltered }\end{array}$ & NW 9 mph & NW 6 mph, light breeze \\
\hline WEATHER/TEMPERATURE & sunny, 70 & Sunny 68 & Sunny 68 , & Sunny 68 & Sunny 68 \\
\hline SURROUNDING FEATURES & $\begin{array}{r}\text { roadside, intermittent } \\
\text { but consistent traffic, } \\
\text { pond/marsh across the } \\
\text { street }\end{array}$ & $\begin{array}{r}\text { open field, BIPC visible } \\
\text { down the hill }\end{array}$ & $\begin{array}{r}\text { yard, road is about } 150 \text { ft } \\
\text { away, BIPC tower is } \\
\text { visible but distant, }\end{array}$ & $\begin{array}{r}\text { mostly empty beach, } \\
\text { close to road but } \\
\text { separated by elevated } \\
\text { dune }\end{array}$ & $\begin{array}{l}\text { wood shop (inactive), } \\
\text { gravel lot, house }\end{array}$ \\
\hline AMBIENT NOISE & cars, pedestrians, birds & $\begin{array}{l}\text { birds, distant cars, distant } \\
\text { ocean, insects/ crickets }\end{array}$ & $\begin{array}{r}\text { some noise from people } \\
\text { in nearby residence } \\
\text { during second reading. } \\
\text { Otherwise birds, } \\
\text { occasional car, distant } \\
\text { construction (beeping) }\end{array}$ & $\begin{array}{r}\text { waves, pedestrians, cars, } \\
\text { birds, distant boat } \\
\text { motors }\end{array}$ & $\begin{array}{r}\text { birds, radio from } \\
\text { woodshop, distant cars, } \\
\text { AC of house nearby }\end{array}$ \\
\hline \multicolumn{6}{|l|}{ EQUIPMENT } \\
\hline DEVICE MODEL/MANUFACTURER & $\begin{array}{r}\text { Advanced Datalogging } \\
\text { Sound Meter } 850013 \text { - } \\
\text { Sper Scientific }\end{array}$ & $\begin{array}{r}\text { Advanced Datalogging } \\
\text { Sound Meter } 850013 \text { - Sper } \\
\text { Scientific }\end{array}$ & $\begin{array}{r}\text { Advanced Datalogging } \\
\text { Sound Meter } 850013 \text { - } \\
\text { Sper Scientific }\end{array}$ & $\begin{array}{r}\text { Advanced Datalogging } \\
\text { Sound Meter } 850013 \text { - } \\
\text { Sper Scientific }\end{array}$ & $\begin{array}{r}\text { Advanced Datalogging } \\
\text { Sound Meter } 850013 \text { - } \\
\text { Sper Scientific }\end{array}$ \\
\hline DEVICE SERIAL \#: & 076142 & 076142 & 076142 & 076142 & 076142 \\
\hline \multicolumn{6}{|l|}{ LAST CALIBRATION DATE? } \\
\hline \multicolumn{6}{|l|}{ NOTES } \\
\hline & & $\begin{array}{l}\text { BIPC worker said points } \\
\text { behind the BIPC would } \\
\text { potentially be louder due to } \\
\text { the exhaust fans that open } \\
\text { in the back. During ambient } \\
\text { measurement, plane over } \\
\text { head at about } 6 \text { min in. } \\
\text { Generators are definitely } \\
\text { audible at this point }\end{array}$ & $\begin{array}{r}\text { Can faintly hear } \\
\text { generators at this } \\
\text { location equivalent to } \\
\text { low level background } \\
\text { noise. Spoke to woman } \\
\sim 100 \text { tt away at around } \\
3 \text { min for second reading. }\end{array}$ & $\begin{array}{r}\text { could not hear } \\
\text { generators when they } \\
\text { were turned on from this } \\
\text { location }\end{array}$ & $\begin{array}{r}\text { at about } 9: 30 \text { minutes } \\
\text { to go, garbage truck } \\
\text { came by (while } \\
\text { generators ON) dB } \\
\text { spiked to } 80 \text {, again at } \\
3: 30 \text { to go }\end{array}$ \\
\hline
\end{tabular}

Table 3. Measurement report data and field notes for all five sites.

The Sper Datalogger Software was also used to analyze the results of the field measurements. This includes visual graph output of all field recordings, as well as statistical analysis of the results including the maximum, minimum, and average noise levels for each field recording. 




Figure 3: example results from the Sper Datalogger Software, showing the maximum, minimum and average between two selected points on the measurement graph (cursors $A$ and $B$ ).

The difference between the first and second noise measurements was calculated for each site, then averaged to produce an average amount of noise reduction in decibels as a result of the diesel generators being turned off.

Calculations:

Site 1 AVG noise reading, generators on - Site 1 AVG noise reading, generators off $=$ difference in noise due to generators for Site 1

$68.93 d B(A)$ to $52.40 d B(A)=16.53 d B(A)$ 


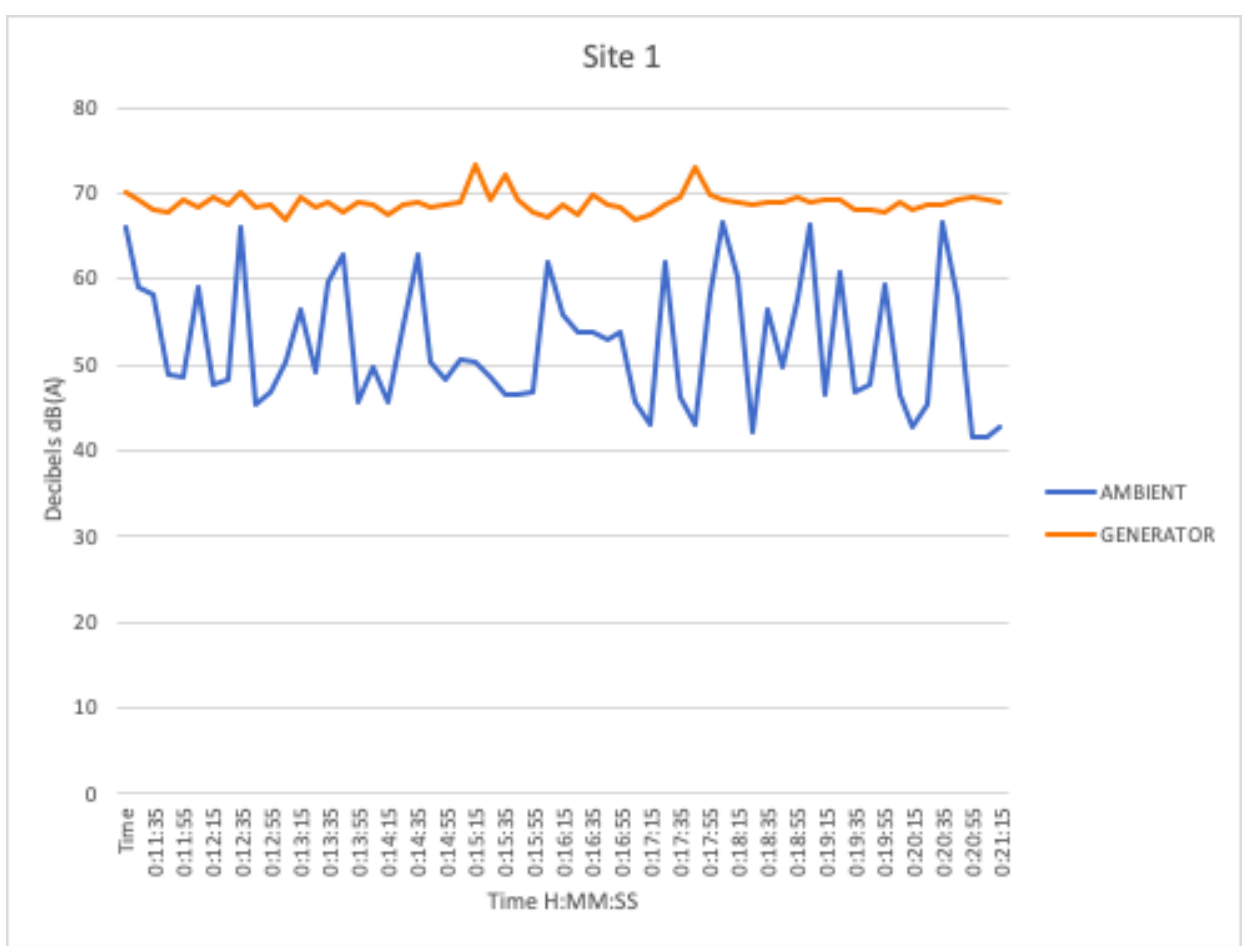

Figure 4. This graph shows the sound data at Site 1 with the generators on (orange) and off (blue).

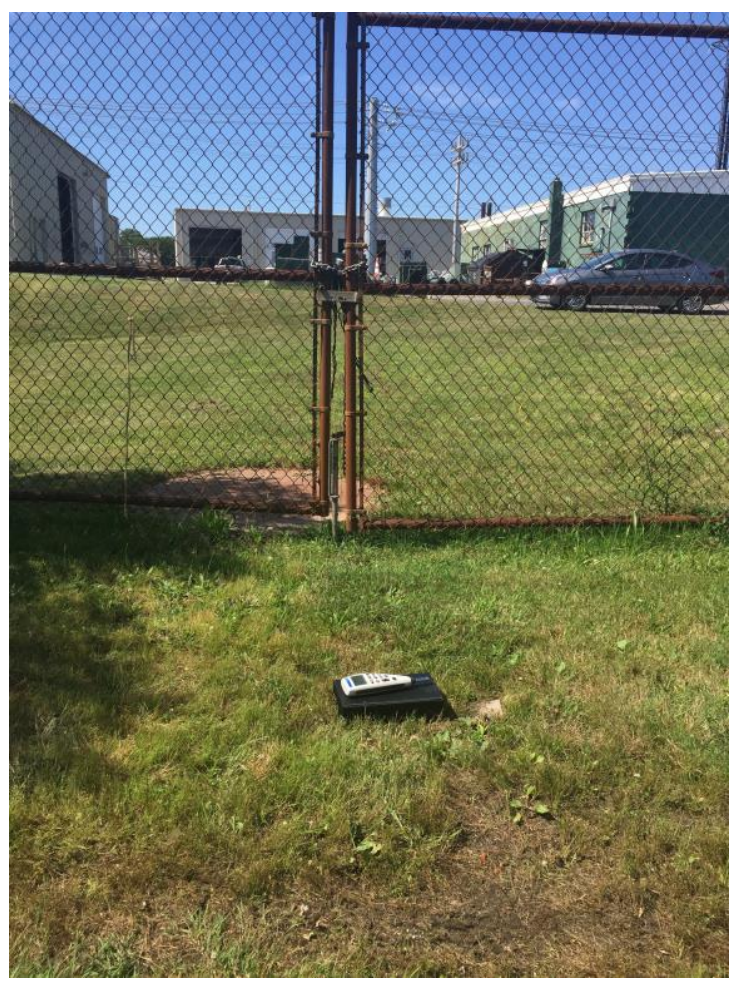

Figure 5. Site 1. Located outside the front gates of the Block Island Power Company. Sound data logger visible in foreground. 
Site 2 noise reading, generators on - Site 2 noise reading, generators off = difference in noise due to generators for Site 2

$51.34 d B(A)$ to $44.47 d B(A)=6.87 d B(A)$

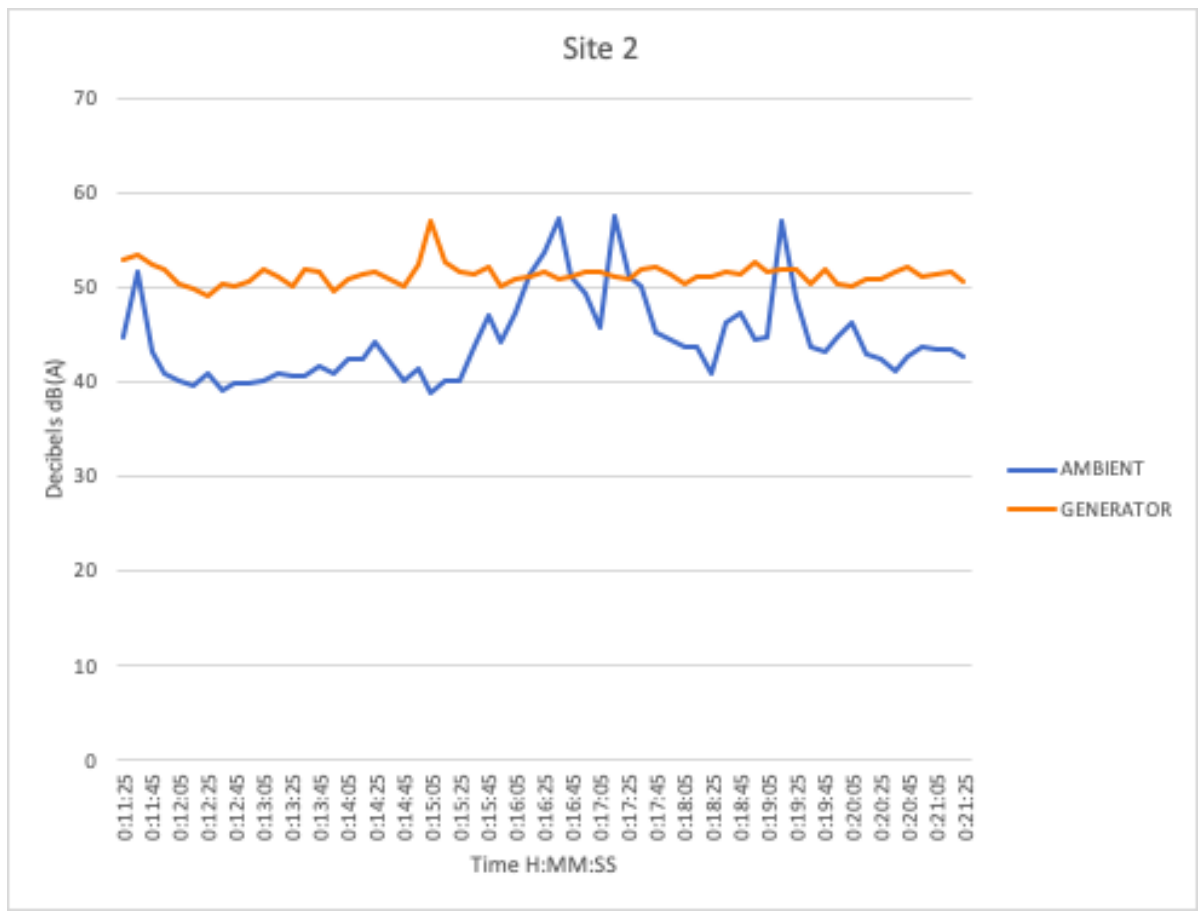

Figure 6. This graph shows the sound data at Site 2 with the generators on (orange) and off (blue).

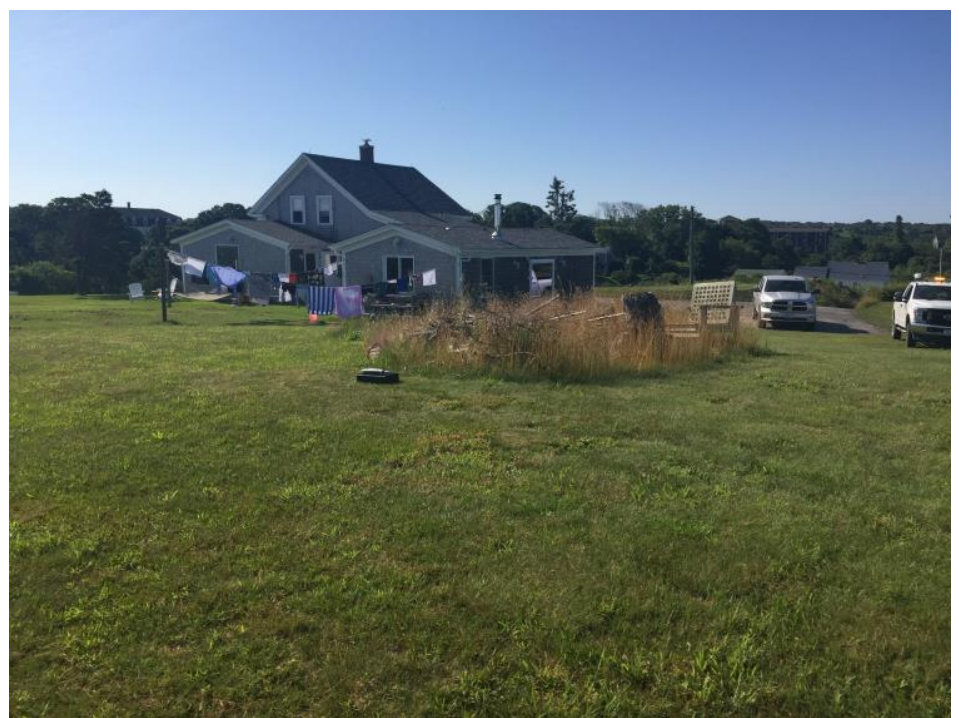

Figure 7. Site 2 view of decibel reader and nearby private residence. Sound data logger is located next to the clump of tall grass. 




Figure 8. Site 2 view of decibel reader facing the Block Island Power Company with cell tower visible.

Site 3 - There was no noticeable difference between generators on and off at this location. This is likely due to the distance of the site from generators and presence of obstacles and ambient noise closer by.

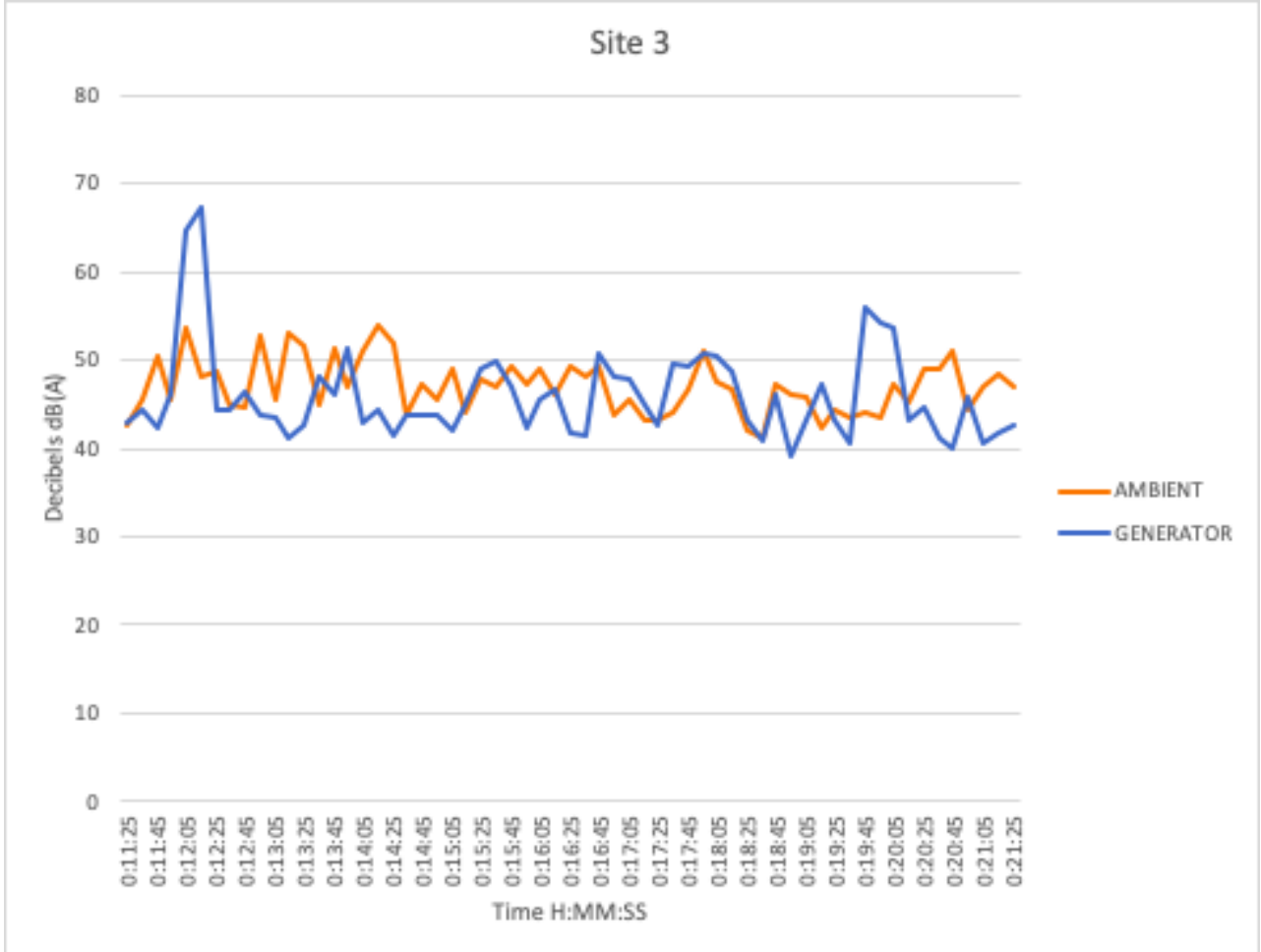

Figure 9. This graph shows the sound data at Site 3 with the generators on (orange) and off (blue). 


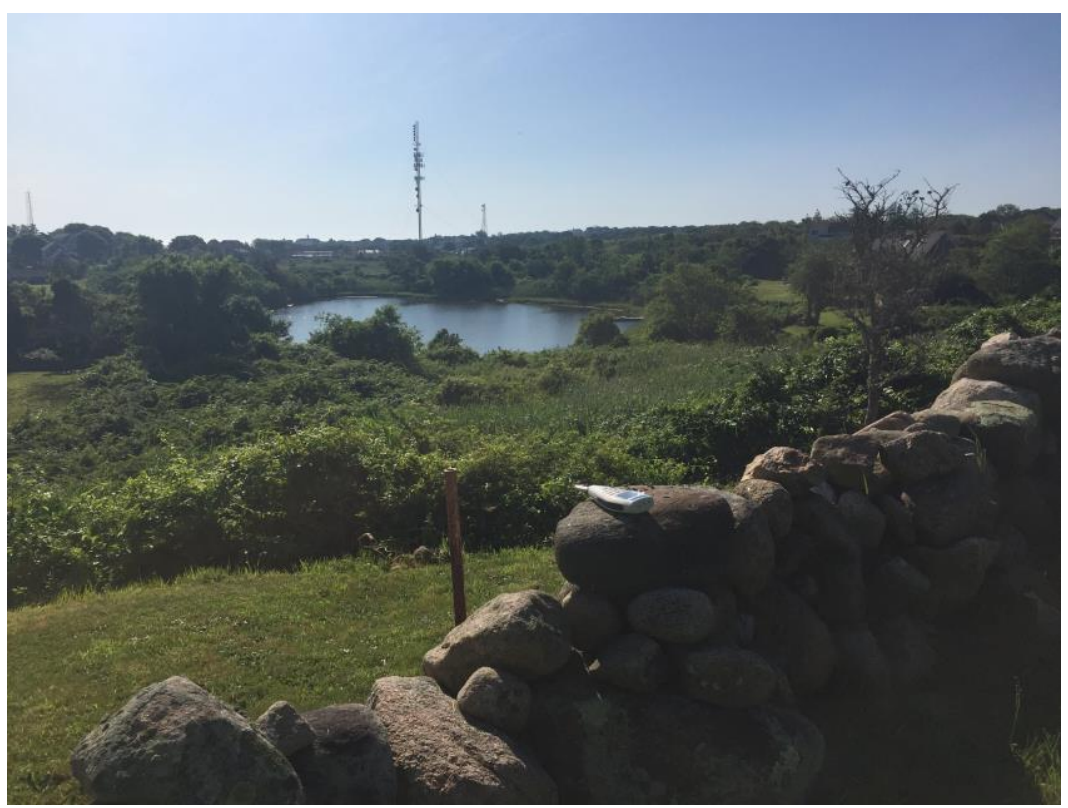

Figure 10. Site 3 view of sound data logger on stone wall of private residence. The Block Island Power Company cell tower is visible in the distance.

Site 4 - There was no noticeable difference between generators on and off at this location. This is likely due to the distance of the site from generators and the presence of heavy ambient noise (waves) nearby.

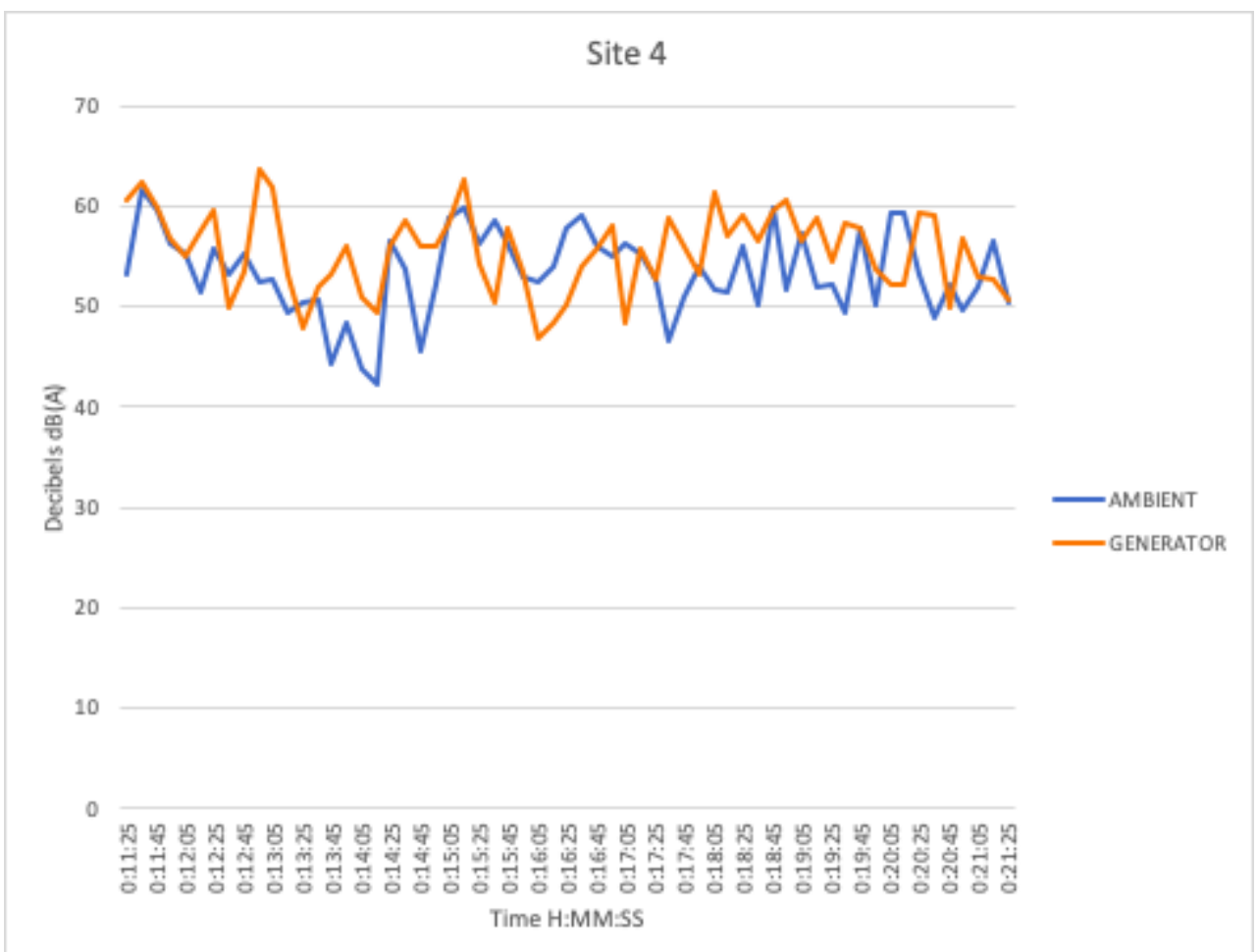

Figure 11. This graph shows the sound data at Site 4 with the generators on (orange) and off (blue). 


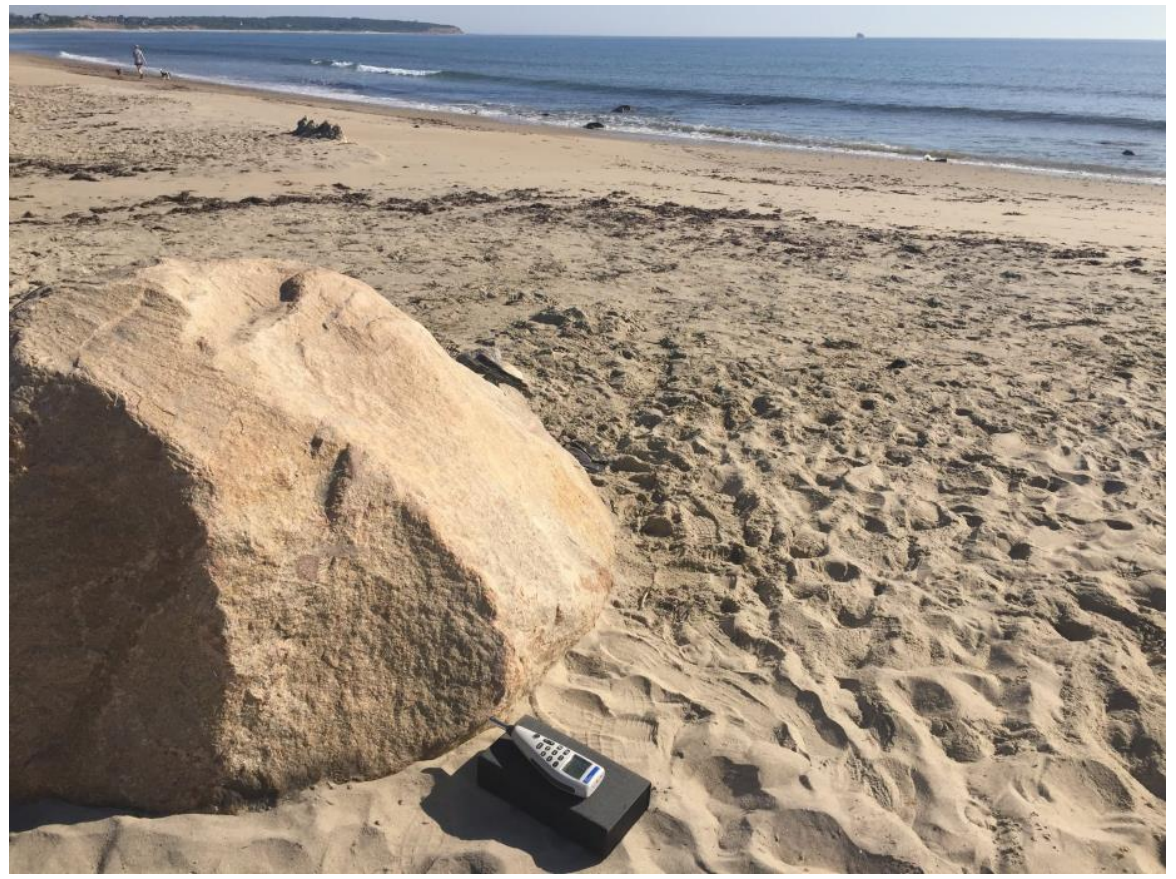

Figure 12. Site 4 view of decibel reader on beach where the ambient noise from waves and wind made the generators inaudible.

Site 5 AVG noise reading, generators on - Site 5 AVG noise reading, generators off $=$ difference in noise due to generators for Site 5

$67.56 d B(A)$ to $48.58 d B(A)=18.98 d B(A)$

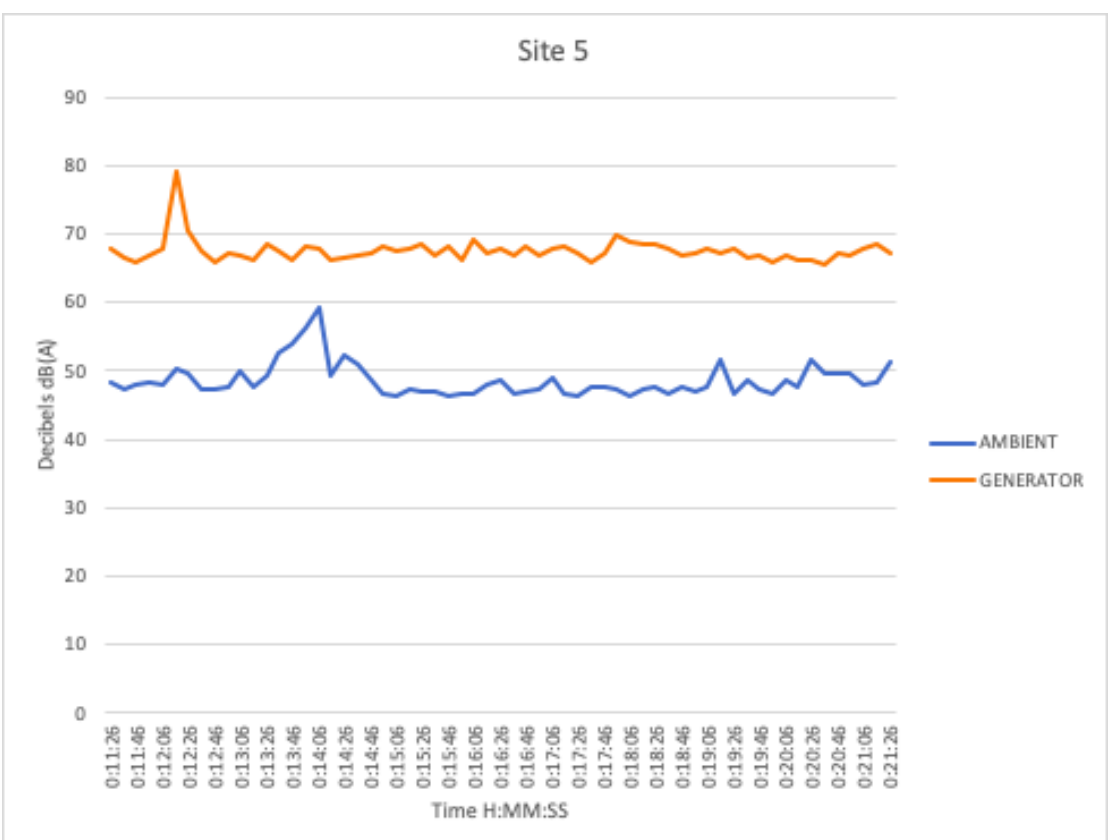

Figure 13. This graph shows the sound data at site one with the generators on (orange) and off (blue). 


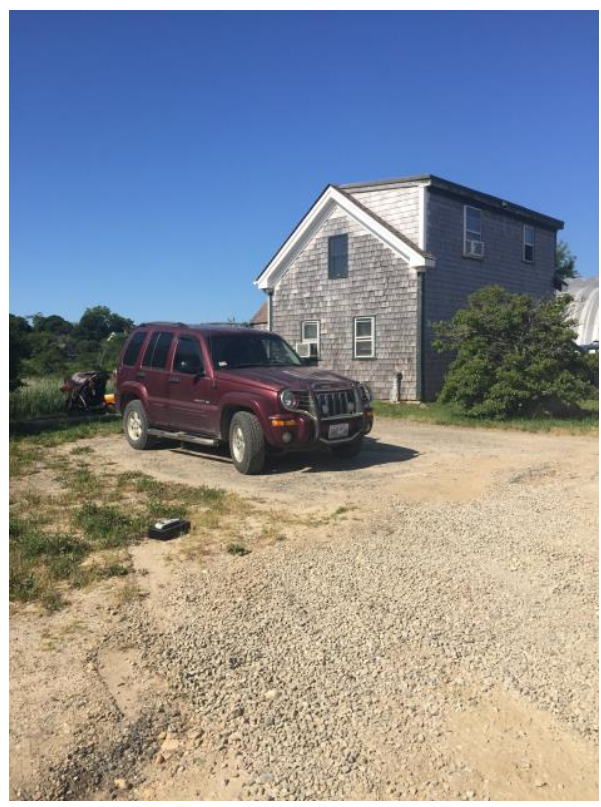

Figure 14. Site 5 is located directly behind the Block Island Power Company and the operating generators. This site was chosen because it is the closest residence to the generators and has been occupied since before the turbine construction was completed.

Difference in noise due to generators for Site $1+$ difference in noise due to generators for Site $2+$ difference in noise due to generators for Site $5=$ total reduction in noise across all three sites

$16.53 d B(A)+6.87 d B(A)+18.98 d B(A)=42.38 d B(A)$

Total reduction in noise across all three sites $/ 3=$ average reduction in noise for Block Island residents as a result of the wind farm

$42.38 d B(A) / 3=14.13 d B(A)$

In addition to the quantitative measurements taken at the 5 sites, testimonials of several locals add to the impact that turning off the generators had on the Island. Testimonials are below:

- Benson, Judy. (2017) Wind Farm Now Powering Block Island. The Day, May, 2017. Accessed on July 29, 2019 at https://www.theday.com/article/20170501/NWS01/170509955

At 5:30 a.m. Monday, Barbara MacMullen went to the Block Island Power Co. to witness history.

"We shut down the diesel generators," said MacMullen, chairwoman of the Block Island Power Co. Transition Team. 
When the noisy, dirty machines the island had depended on for decades for its power were turned off, she and others gathered there heard birds singing and reveled in the latest milestone for this small island's journey to renewable energy.

"It feels so great," she said (Benson, 2017)

- While conducting the sound measurements, a comment by a BIPC employee who has been with the company for 47 years remarked on the completion of the BIWF and the silencing of the generators, that it was one of the only times when the generators being off did not signal a problem or emergency where employees would rush to restore power to the island.

- This same employee also remarked on the company receiving multiple or regular complaints from a few nearby residents about the noise and concern for health and safety.

- Current BIPC president Jeff Wright recalled multiple employees being emotional at the time the generators turned off because it signified such a monumental change for their lives and the lives of those on the island.

- A video of the moment the generators were turned off was posted to the BIPC's Facebook page which demonstrates firsthand the difference in noise for the employees of the company and the immediately audible birds chirping in the background.

\section{https://www.facebook.com/1100746530053932/videos/1168424626619455/}

\section{Sources:}

Brüel \& Kjær Booklet: Environmental Noise Measurement (BR1626).

Minnesota Pollution Control Agency. (2015). A guide to Noise Control In Minnesota: Acoustical Properties, Measurement, Analysis and Regulation.

\section{Limitations:}

Only a few locations were sampled for noise readings, and therefore the study cannot account for the wide range of noise levels experienced throughout the island at various proximity to the diesel generators. The noise readings were taken on a single summer day during the busy summer tourism season, and therefore cannot account for the various wind, weather, traffic, and other noise conditions which fluctuate from day to day throughout the year, and could potentially mitigate some of the noise of the generators.

Additionally, the generators did not run consistently 24 hours a day, 7 days a week before the wind farm was implemented. The average noise reduction can only account for the noise produced by the generators, and not for the percentage of time that the generators would be in operation during any given day.

Lastly, all four generators were turned on at once for the second noise readings. This mimics the heaviest use scenario, likely to occur only during the island's busiest summer tourism 
months of July and August. Noise readings with fewer generators in operation were not taken, which could provide additional data which could mimic off-season conditions.

\section{Economic Benefits}

\section{- Created 300 temporary local jobs during the construction of the wind turbines.}

Methods: As a contribution to a rise to local employment during the construction operation, the project provided 300 temporary employment opportunities for local residents. Information publicly available on Deepwater Wind's web page.

Source:

Deepwater Wind. http://dwwind.com/project/block-island-wind-farm/

Limitations: This was not independently verified by the research team.

- Contributed to a $19 \%$ increase in occupancy and an $\$ 3,490$ increase in total monthly revenue for online home sharing marketplace properties on Block Island during the peak tourism months of July and August when comparing pre-and post-construction rates.

Methods:

This information is based on review of a study that referenced and analyzed AirBnb rental data for a 39 month period starting in October 2014 to December 2017. The full data set consists of 1,368 rental properties, and $\$ 39.5$ million in transaction revenue.

Several measures were taken in the study to ensure this data set fully represented the desired control and treatment groups. For example, 630 properties that were open only during the post treatment properties were eliminated. This was important due to the fact that representatives from AirBnb visited Block Island to encourage established bed and breakfast properties to use their platform shortly before construction of the BIWF. These post construction properties would have no pre-construction equivalent for comparison and their emergence cannot be attributed to the completion of the BIWF since the visit from AirBnb representatives coincides.

120 properties that were active only during the pre-treatment (pre-construction) period were also eliminated from the final sample. Further controls for differences in both year-long and seasonal activity were taken into account, as well as unobservable time-invariant factors such as nearby amenities and online appeal, and other extraneous factors such as minimum stay/maximum guest requirements, cleaning fees, security deposits, etc. 
Dependent variables of 'available nights', 'reservation nights', 'occupancy rates', 'average booked rate', and 'revenue' were compared to Block Island data pre-construction of the BIWF as well as similar tourist locations in Narragansett, RI, Westerly, RI and Nantucket, MA.

A significant difference in available nights, reservation nights, and revenue models were observed post treatment and a more significant increase during the peak tourism months of July and August. This indicated not only an increase in the available nights dictated by rental property owners, but a consumer interest indicated by the significant increase in reservation nights and also revenue.

In conclusion the original study's researchers found that the significant increase in occupancy rate $(18.8 \%)$ and in revenue $(\$ 3490)$ during the peak tourism months of July and August was highly unlikely ( $1 \%$ and $5 \%$ respectively) to be due to chance, and therefore there is a strong probability ( $99 \%$ and (5\% respectively) that the BIWF positively impacted these tourism metrics (See Table 4). 


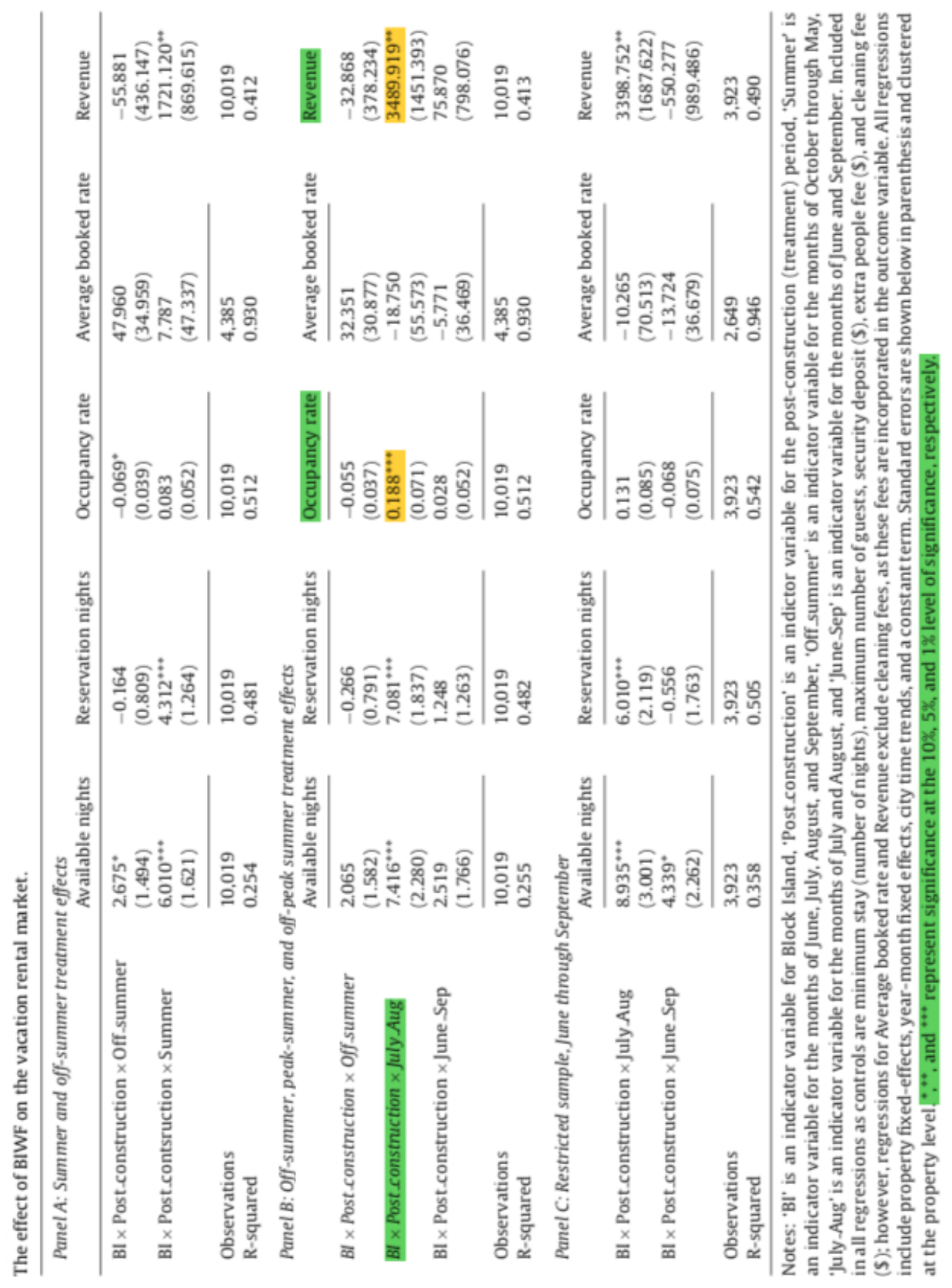

Table 4. This table from Carr-Harris and Lang 2019 highlights the key results in yellow with parameters and significance noted in green.

Sources:

Carr-Harris, Andrew, and Corey Lang. 2019. "Sustainability and tourism: the effect of the United States' first offshore wind farm on the vacation rental market". Resource and Energy Economics. 57: 51-67. 


\section{Limitations:}

Even in the absence of the construction of BIWF, market fluctuations would continue. Thus for control scenarios such as pre-construction Block Island or non-Block Island tourist sites, the study cannot assume a complete absence of treatment or changes in the economy. To account for this the current rate of change is assumed to be constant for the duration of the study.

It also assumes that AirBnb data is an accurate stand in for, if not general tourism, than overall rental property trends on the island. There is the possibility that rental trends would change if data from non-AirBnb or from other rental platforms was included.

Another assumption is that the BIWF had no effect on the control markets of Nantucket, Narragansett, or Westerly. It is possible that positive attraction of tourists to Block Island could displace reservations in control locations, or alternatively that repulsion towards Block Island after wind farm construction could increase tourism in control locations.

"Almost certainly, there are tourists that are attracted by and repulsed by the BIWF and everywhere in between. Our measures are aggregate, and we cannot distinguish preferences of individuals or even the proportion of tourists falling into different categories." (Carr-Harris and Lang 2019, p.6)

\section{Cost Comparison}

- Assembly and installation of the BIWF cost an estimated \$20,880,240 million through the use of a flexible "Twisted Jacket" ocean floor anchoring system, compared to an estimated \$26,100,300 million for installation of a more traditional monopile anchoring system. The "Twisted Jacket" has fewer parts leading to a reduction in steel usage due to more efficient weight distribution. It is also faster to assemble than the monopile system, while retaining the same anchoring capacity and ability to withstand storms.

Methods: Unlike onshore wind farms, the offshore Block Island Wind farm construction required the consideration of both aerodynamic and hydrodynamic loading. In order to meet the challenging demands of such a dynamic environment, engineers needed to understand extreme loading situations such as hurricane-force winds and mechanisms for both controlled shutdowns and emergency shutdowns, as well as model how the turbines and their support platforms would withstand such circumstances over a 20-year design life span.

The use of a software specifically for the structural analysis for the design, fabrication, installation, operations, and maintenance of offshore structures (Bentley SACS®) was instrumental in the successful design of the turbine support structures by the engineer (Keystone). Using this software the platform foundations (or jackets) were designed using complex nodal geometry which formed a steel lattice system with multiple anchoring points to 
the sea floor. This form is an alternative to other typical offshore wind monopile concrete foundations that are limited to shallower depths. According to a publication by Keystone Engineering in 2016 titled the "Inward Battered Guide Structure", the "Twisted Jacket" foundation system has fewer parts and is easier to assemble, and has a reduction in steel costs due to more efficient weight distribution. On average, the use of the "Twisted Jacket" structure results in savings of installation costs by over 20 percent compared to traditional monopile construction. For this analysis, $20 \%$ savings was assumed.

SACS software as well as DNV GL's Bladed (a wind turbine simulation tool) were used to run a series of rigorous virtual tests to optimize the design of the turbines' support structures. For each design iteration, 2,334 simulations were run. These included 30 million time steps and 25 load scenarios for waves up to 19 meters high and winds from 8 directions at speeds ranging from 2 to 58 meters per second. The categories of load scenarios explored include: 'operating', 'storm', 'startup', 'shutdown', 'fault', 'maintenance', and 'installation'. The nearly 10 million tests run over 150 simulations reduced the cycle time by 50 percent as compared to typical European offshore wind projects.

Because financial information for the Block Island Wind Farm's construction is not publicly available, we needed to refer to a study which use reference projects to calculate general construction costs of similar projects. The study, titled the National Renewable Energy Laboratory 2016 Cost of Wind Energy Review, presents a sample offshore fixed-bottom reference project. This sample project combines data from multiple offshore projects proposed or installed in 2016, providing an overall set of performance metrics to serve as a reference point for comparison of similar projects. In creating these aggregate metrics, the study takes into account characteristics such as water depth and distance from shore to ensure that the data is comparable to sites on the U.S. North Atlantic Coast.

The calculated capital expenditure the BIWF was informed by The National Renewable Energy Laboratory's (NREL's) Offshore Wind Database. The database includes information on 7 offshore wind projects installed in 2016 which correspond to 1,188 MW of capacity. The data were obtained through analysis of global market data, literature review, review of current press statements, and industry collaboration. The offshore fixed-bottom reference project is intended to be representative of near-term offshore wind projects likely to be developed in the North Atlantic region of the United States. The total capital expenditure to install the the entire wind farm was calculated based on the cost per kilowatt-hour for a typical fixed-bottom project, using the total combined turbine output of five $6 \mathrm{~mW}$ turbines. From this cotal capital expenditure cost, a percentage was taken to determine the cost of assembly and installation for the entire project. A $20 \%$ reduction in this assembly and installation cost was calcualted, which is the final construction savings as a result of using a monopile vs. "twisted jacket" foundation system.

ABBREVIATIONS:

CapEx = capital expenditures

LCOE = levelized cost of energy 


\begin{tabular}{|lc|}
\hline \multicolumn{2}{|c|}{$\begin{array}{c}\text { Project Parameters } \\
\text { Fixed-Bottom/Floating } \\
\text { Substructures } \\
\text { North Atlantic }\end{array}$} \\
\hline Location & 4.71 \\
\hline Turbine rated power (MW) & 128 \\
\hline Number of turbines & 600 \\
\hline Wind plant capacity (MW) & $30 / 100$ \\
\hline Water depth (m) & Monopile/semisubmersible \\
\hline Substructure type & 30 \\
\hline Distance from shore (km) & 20 \\
\hline Project design life (years) & \\
\hline
\end{tabular}

Table 5. Offshore Reference Project Parameters (Fixed Bottom and Floating Substructures) according to Stehly, T., Heimiller, D, and Scott, G. 2016 Cost of Wind Energy Review.

\begin{tabular}{|c|c|c|}
\hline & $\begin{array}{c}\text { 4.71-MW Offshore } \\
\text { Turbine } \\
(\$ / k W)\end{array}$ & $\begin{array}{c}\text { 4.71-MW Offshore } \\
\text { Turbine } \\
\text { (\$/MWh) }\end{array}$ \\
\hline TURBINE CAPITAL COST & 1,505 & 42.6 \\
\hline Development cost & 66 & 1.9 \\
\hline Engineering management & 71 & 2.0 \\
\hline Substructure and foundation & 639 & 18.1 \\
\hline Site access, staging, and port & 21 & 0.6 \\
\hline Electrical infrastructure* & 411 & 11.6 \\
\hline Assembly and installation & 872 & 24.7 \\
\hline Plant commissioning & 36 & 1.0 \\
\hline BALANCE OF SYSTEM & 2,115 & 59.8 \\
\hline Insurance during construction & 46 & 1.3 \\
\hline Decommissioning bond & 222 & 6.3 \\
\hline Construction financing & 294 & 8.3 \\
\hline Contingency & 397 & 11.2 \\
\hline FINANCIAL COSTS & 959 & 27.1 \\
\hline TOTAL CAPITAL EXPENDITURES & 4,579 & 129.5 \\
\hline
\end{tabular}

Table 6. Fixed Bottom Offshore Capital Expenditure (CapEx) and (Levelized Cost of Energy) LCOE Breakdown. According to Stehly, T., Heimiller, D, and Scott, G. 2016 Cost of Wind Energy Review. 




Figure 15. Capital expenditures for the fixed bottom offshore wind reference project. Graph reference: Stehly, T., Heimiller, D, and Scott, G. 2016 Cost of Wind Energy Review.

Calculations:

(all calculations rounded to the nearest dollar)

\section{Capital Expenditures to install turbines of BIWF}

The NREL model CapEx value for an offshore wind power plant with turbines being supported by monopile fixed-bottom substructures: $\$ 4,579 / \mathrm{kW}$

$\$ 4,579 / \mathrm{kW} \times 1,000=\$ 4,579,000 / \mathrm{mW}$

$\$ 4,579,000 / \mathrm{mW} \times 6 \mathrm{~mW}$ (total BIWF turbine capacity) $=\$ 27,474,000$ CapEx per turbine $\$ 27,474,000 \times 5$ turbines $=\$ \mathbf{1 3 7 , 3 7 0 , 0 0 0}$ total CapEx for BIWF (including Turbine, Balance of System, and Financial - see Fig X).

\section{Cost of assembly and installation}

Assembly and Installation $=19.0 \%$ of total capital expenditures cost for BIWF $\$ 137,370,000$ total capital expenditures cost for BIWF x .19=\$26,100,300 cost of Assembly and Installation 
Calculation of reduction in construction cost by $20 \%$ $\$ 26,100,300$ cost of Assembly and Installation x.20 $=\$ 5,220,060$ reduction in construction costs

$\$ 26,100,300-\$ 5,220,060=\$ \mathbf{2 0 , 8 8 0 , 2 4 0}$ lower project cost due to use of "Twisted Jacket" system.

\section{Sources:}

Keystone Engineering, 2016. Inward Battered Guide Structure, the "Twisted Jacket." https://issuu.com/keystoneengineering/docs/ibgs brochure iii issuu

Bentley Systems, Incorporated, 2016. "Case Study: Keystone Engineering Designs First Commercial Offshore Wind Farm in the U.S." https://prodbentleycdn.azureedge.net/en/perspectives-and-viewpoints/topics/viewpoint/cs-keystoneengineering-designs-first-commercial-offshore-wind-farm-2015

National Renewable Energy Laboratory (U.S.). 2016. Cost of wind energy review. https://www.nrel.gov/docs/fy18osti/70363.pdf

Block Island Wind Farm and Block Island Transmission System Environmental Report/Construction and Operations Plan, 2012, Deepwater Wind: http://dwwind.com/wpcontent/uploads/2014/08/Environmental-Report-Exec-Summary.pdf

Limitations: The unavailability of actual construction cost data for BIWF limits the degree to which the cost savings reflect those actually achieved by the specific project. For example, the total capital expenditures calculated for the project is $\$ 137,370,000$ based off of the reference project data, which differs significantly than the $\$ 290$ million budget most commonly used in publications referring to this project.

Reference project data cannot perfectly mimic the attributes of one specific project, relying instead on aggregate data that is by definition an approximation of the characteristics of a project. Additionally, some of the reference project's parameters, shown above in table 5, do not align with those of the BIWF. The parameters that do not align with the BIWF are the following:

- The reference project wind power plant consists of 128 wind turbines each rated at 4.71 MW, equating to a $600-M W$ wind power plant capacity. The BIWF consists of 5 wind turbines each rated at $6 \mathrm{MW}$, equating to a $30-\mathrm{MW}$ wind power plant capacity.

- The reference project assumes a grid turbine layout, whereas the BIWF has a linear layout.

- The array cable system and electrical line that connects to the offshore substation of the reference project is a 33-kilovolt collection system design, whereas the BIWF has a 34.5-kilovolt collection system. 
- The export cable from the offshore substation that is used to transfer the power to landfall assumes a 220-kilovolt export system. The BIWF uses another 34.5-kilovolt collection system to transfer power to landfall. 